\title{
Toxoplasmosis in squirrel monkeys: histological and immunohistochemical analysis
}

\author{
Toxoplasmose em macacos-de-cheiro: análise histológica e imunoistoquímica

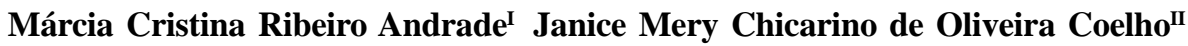 \\ Maria Regina Reis Amendoeira ${ }^{\text {III }}$ Regiane Trigueiro Vicente ${ }^{\text {III }}$ \\ Célia Virgínia Pereira Cardoso'Paola Cristina Brandão Ferreira ${ }^{\mathrm{I}}$ \\ Renato Sergio Marchevsky ${ }^{\text {IV }}$
}

\section{ABSTRACT}

Necropsy findings in three cases of naturally occurring toxoplasmosis in squirrel monkeys (Saimiri sciureus) obtained as wild catches from the Amazon region were described. Histopathological evaluation of the liver, spleen, kidneys and mesenteric lymph nodes showed multiple foci of inflammation and necrosis. Typical, well-defined morphologic Toxoplasma gondii cysts and free forms of the parasite were found by immunoperoxidase staining within inflammatory infiltrates. The presence of T. gondii in the studied colony could severely influence the results of experiments performed in the animals.

Key words: squirrel monkeys, neotropical primates, toxoplasmosis, immunohistochemical analysis, serology.

\section{RESUMO}

Achados de necropsia em três casos de toxoplasmose ocorridos naturalmente em macacos-de-cheiro (Saimiri sciureus) obtidos de capturas na região Amazônica foram descritos. A avaliação histopatológica do fígado, baço, rins e linfonodos mesentéricos mostrou múltiplos focos de inflamação e necrose. Cistos morfológicos típicos e bem definidos de Toxoplasma gondii e formas livres foram detectados pelo método da imunoperoxidase com infiltrados inflamatórios. A presença de T. gondii na colônia de primatas estudada pode influenciar severamente os resultados de experimentos realizados nos animais.

Palavras-chave: macacos-de-cheiro, primatas neotropicais, toxoplasmose, análise imunoistoquímica, sorologia.

\section{INTRODUCTION}

Toxoplasma gondii is an obligate intracellular coccidian parasite with a global distribution and a wide range of warm-blooded animal hosts. There are many reports of toxoplasmosis in New World primates, which are much more susceptible than Old World primates, rarely surviving the disease (EPIPHANIO et al., 2003). Squirrel monkeys (Saimiri sciureus) were susceptible to experimental infection with $\boldsymbol{T}$. gondii, frequently developing an acute multifocal necrotizing inflammation usually a highly fatal disease (ANDERSON \& McCLURE, 1982). Spontaneous cases of fulminating fatal toxoplasmosis were reported in immunologically normal adult squirrel monkeys (INOUE, 1997).

This report is based on the histological and immunohistochemical findings in three cases of naturally occurring toxoplasmosis in S. sciureus obtained as wild catches from the Amazon region.

\section{MATERIAL AND METHODS}

A long-term inbreed colony of about 50 squirrel monkeys (Saimiri sciureus) from the Primatology Department of the Center for Laboratory Animal Breeding of the Oswaldo Cruz Foundation

\footnotetext{
ICentro de Criação de Animais de Laboratório (CCAL), Fundação Oswaldo Cruz (FIOCRUZ). Av. Brasil, 4365, 21040-900, Manguinhos, Rio de Janeiro, RJ, Brasil. E-mail: andrade@fiocruz.br. Autor para correspondência.

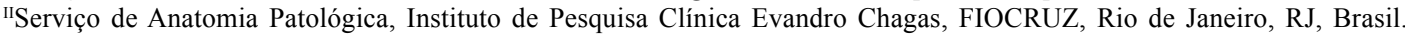

IIIInstituto Oswaldo Cruz, Departamento de Protozoologia, Laboratório de Toxoplasmose, Rio de Janeiro, RJ, Brasil.

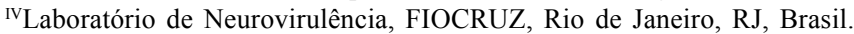


(FIOCRUZ), Rio de Janeiro, RJ, Brasil was analyzed. Nonhuman primates are used for biomedical research. The study colony was established in 1987 from a founding stock of 150 individuals, housing animals rescued from the Balbina and Samuel hydroelectrical plant reservoir areas in the Amazon region, with the intent to develop a vaccine against malaria under a scientific cooperation agreement with the Rockefeller Foundation. The formed colony is kept in a special type of cage, in its own built in a manner that makes good use of manual lighting, simulating its wild habitat.

Animals are housed in single male breeding groups of 10-15 primates. Their diet consists of fruits, vegetables, commercial monkey chow, and water with added minerals and vitamins. Annual health assessments are performed on all nonhuman primates, including tuberculin skin-testing, biometry, detailed clinical examination, collection of blood and feces for routine laboratory tests (hemogram, serum chemistry, and parasitology examination). Serum samples are archived in a recently established reference serum bank for future seroepidemiologic studies.

A complete gross necropsy was conducted on three adult males squirrel monkeys that were housed in the Fiocruz Primate Center and died without apparent clinical manifestations. The dead animals came from the Amazon region, hence an exact age was not known. Through biometry and dentition analysis, we reached the ages 6,9 , and 11 years at the death event. In all cases, animals were found dead on the floor cage without previous described clinical history. The animals were not submitted to any experimental procedure as they belonged to the animal breeding program.

Tissues were collected and preserved in neutral-buffered $10 \%$ formalin, dehydrated and embedded in Paraplast ${ }^{\circledR}$. Sections $(4 \mu \mathrm{m})$ were stained with hematoxylin and eosin (HE). Additional stainings of PAS and Giemsa were performed. Sections $(4 \mu \mathrm{m})$ from blocks, after mounting on Polysine(tm) (ESCO) coated glass slides, were submitted to immunoperoxidase technique. Tissue sections were incubated with biotinylated anti-mouse/anti-rabbit antibody (LIPSHAW) followed by peroxidase labeled streptavidin-peroxidase complex (LSAB, DAKO) using diaminobenzidine (DAB) chromogen as substrate. Sections were stained with Meyer hematoxylin and analyzed by light microscopy to find T. gondii components.

In view of the histopathological findings, seroprevalence of T. gondii in the squirrel breeding monkeys must be determined, with the goal of defining health status of the colony. Thus, a serosurvey was conducted on all animals of the colony by enzymelinked immunosorbent assay (ELISA) for primary antibody screening of serum samples. Assays detected simian IgG and IgM. A commercially available ELISA kit for Toxoplasma gondii antibody testing (IgG Zeus, Trinity Biotech ${ }^{\circledR}$, São Paulo, Brazil; IgM Enzywell, Diesse Diagnostica Senese $\mathrm{SpA}^{\circledR}$, Monteriggioni, Italy) was used. Commercial assay was conducted in accordance with manufacturer's instructions.

In order to confirm the serological diagnosis by ELISA, the indirect immunofluorescence technique preconized by CAMARGO (1964) was performed. Standard antigen was covered with $0.01 \mathrm{ml}$ of fourfold dilutions (from 1:16 to 1:4.096) of the examined sera and each smear was covered with diluted anti- IgG and IgM FITC conjugate $\left(\right.$ Sigma $\left.^{\circledR}\right)$. Both tests were repeated for confirmation one year after this analysis. No serological test was performed in the animal population before this report.

\section{RESULTS AND DISCUSSION}

No IgG was detected against T. gondii by both adopted techniques in the animal population. Only one animal presented IgM positive through ELISA. However, neither the indirect immunofluorescence nor the second ELISA test confirmed the positivity. This particular animal presents no clinical signs.

With regards to the most common necropsy findings of the three squirrel monkeys, splenomegaly, pulmonary congestion, and enlarged mesenteric lymph nodes were verified. Fatal infections were characterized by degenerative changes with vacuolization and haemosiderosis and scattered necrotic foci in the lung, kidney, liver and mesenteric lymph node with or without an inflammatory response. Typical, well-defined free forms and cysts of $\boldsymbol{T}$. gondii were identified by immunoperoxidase staining associated with inflammation or in necrotic foci of affected organs (Figure 1). Most of the histopathological findings here described confirmed those reported by EPIPHANIO et al. (2003).

Since the three necropsied animals presented sudden death, antibodies anti-T. gondii titer was not possible. Besides, except for hemogram and serum chemistry as routine, no other previous laboratorial examination was carried out. The hematological picture in such animals, however, was in accordance to normal parameters for the species.

Toxoplasmosis is a zoonosis of worldwide distribution and is considered to be a fatal parasitic disease of New World primates (EPIPHANIO et al., 2003) due to the impracticability of controlling the 

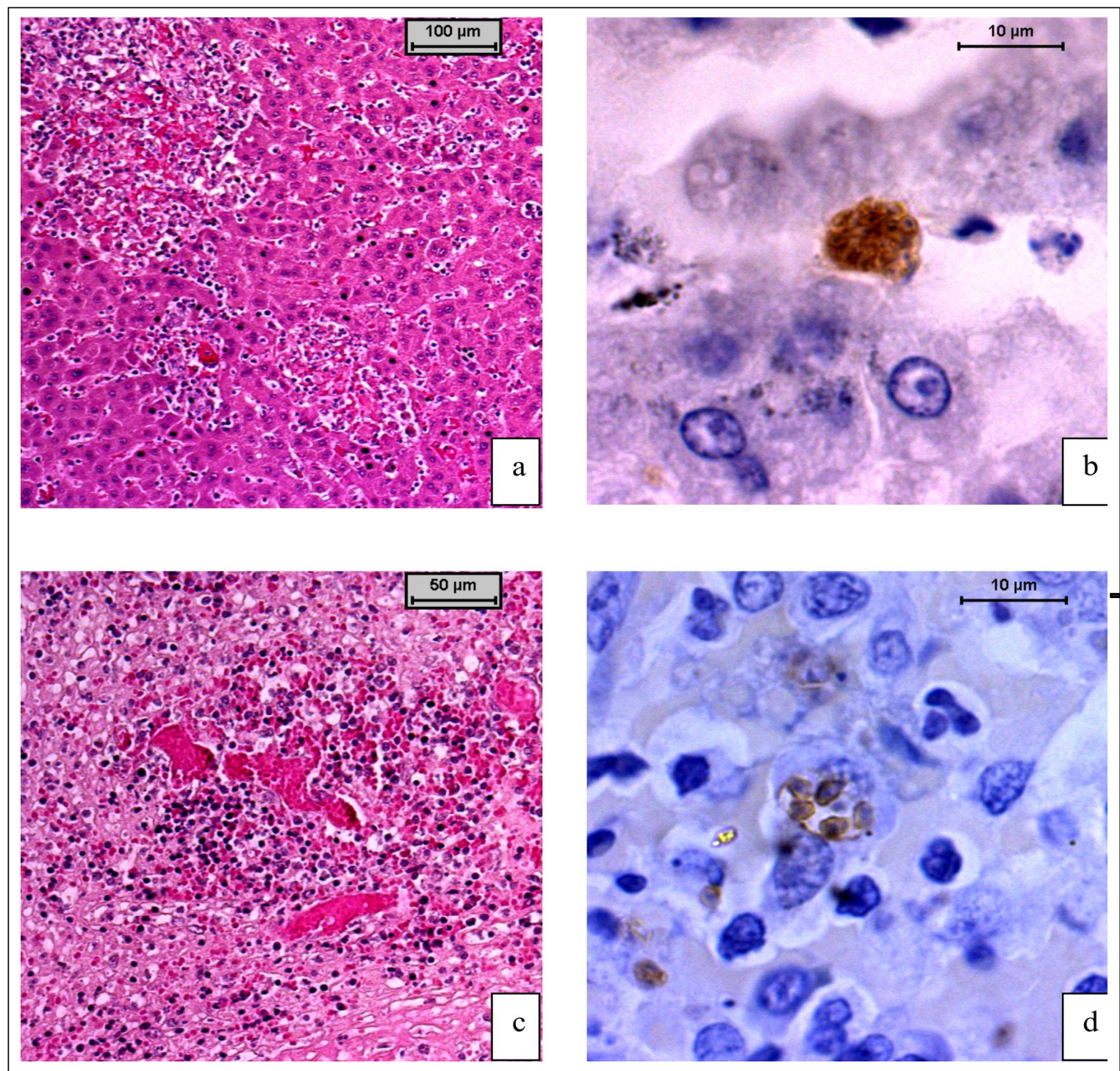

Figure 1 - a: Saimiri sciureus - liver with multifocal necrotizing hepatitis, HE (x100); b: liver - Toxoplasma gondii cyst. Immunostaining (x1250); c: lymph node - necrotizing lymphadenitis, H.E (x200); d: lymph node - Toxoplasma gondii free forms. Immunostaining (x1250).

potential mechanical vectors such as meal worms and cockroaches and to the lack of an efficacious vaccine. In this study the source of the infection was not determined.

Although the immunity mechanisms in toxoplasmosis are complex and multifactorial (EPIPHANIO et al., 2003), a clinical health monitoring program for nonhuman primates maintained in captivity must include serum samples for the presence of antibodies to T. gondii as one more tool to investigate this protozoa. A serological survey of squirrel monkeys captured in the Amazon region of Brazil showed that 24 of 49 sera were positive to T. gondii (FERRARONI
\& MARZOCCHI, 1980). Considering the serological profile of the studied squirrel monkeys colony, in the toxoplasmosis cases here described, animals could be infected where they came from since no IgG antibodies were detected in any animal of the whole colony.

Proper conditions of hygiene and sanitation of the cages as well as animal management techniques should be evaluated to avoid the possibility of an outbreak. CUNNINGHAM et al. (1992) described an acute, fatal epidemic of toxoplasmosis, which caused $30 \%$ mortality and an apparent $100 \%$ morbidity in a captive colony of squirrel monkeys ( $\boldsymbol{S}$. sciureus) housed in a zoo. The fact that $\mathbf{T}$. gondii can easily infect squirrel 
monkeys and produce fatal disease, indicates that persons who are working with squirrel monkeys in zoos or keeping them as pet in the house should be aware of their susceptibility to toxoplasmosis and take proper precautions to decrease or to prevent their exposure to contaminated caging facilities and foods with $\mathbf{T}$. gondii. DIETZ et al. (1997) considered that rodents, insects, and feeding stuff are important sources of contamination.

Since the colony under study is used for biomedical research, the presence of $\mathbf{T}$. gondii could severely influence the results of the animal experiments performed with the animals. According to the findings of FURUTA et al. (2001), transmission of T. gondii from infected monkeys to cagemates occurs easily. Also, aerosol infection could play an important role for the enzootic toxoplasmosis in colonies of squirrel monkeys. ESCAJADILLO \& FRENKEL (1991) reported that contact infection of T. gondii may occur between infected aotus monkeys and their cagemates, although the clear route of contact infection was not determined. They showed that toxoplasma tachyzoites were present in milk, saliva, urine or feces and may be ingested by cagemates. Therefore, rigorous prophylactic procedures are necessary to prevent the occurrence of this protozoosis in captive colonies.

\section{REFERENCES}

ANDERSON, D.C.; McCLURE, H.M. Acute disseminated fatal toxoplasmosis in a squirrel monkey. Journal of American Veterinary Medical Association, v.181, p.1363-1366, 1982.

CAMARGO, M.E. Improved technique of indirect immunofluorescence for serological diagnosis of toxoplasmosis. Revista do Instituto de Medicina Tropical de São Paulo, v.6, p. 117-118, 1964 .

CUNNINGHAM, A.A. et al. An epidemic of toxoplasmosis in a captive colony of squirrel monkeys (Saimiri sciureus). Journal of Comparative Pathology, v.107, p.207-219, 1992.

DIETZ, H.H. et al. Toxoplasmosis in a colony of new world monkeys. Veterinary Parasitology, v.68, p.299-304, 1997.

EPIPHANIO, S. et al. Pathology of toxoplasmosis in captive new world primates. Journal of Comparative Pathology, v.129, p.196-204, 2003.

ESCAJADILLO, A.; FRENKEL, J.K. Experimental toxoplasmosis and vaccine in Aotus monkeys. American Journal of Tropical Medicine Hygiene, v.44, p.382-389, 1991.

FERRARONI, J.J.; MARZOCHI, M.C. Prevalence of Toxoplasma gondii infection in domestic and wild animals, and human groups of the Amazonas region. Memórias do Instituto Owaldo Cruz, v.75, p.99-109, 1980.

FURUTA, T. et al. Horizontal transmission of Toxoplasma gondii in squirrel monkeys (Saimiri sciureus). Experimental Animal, v.50, p.299-306, 2001.

INOUE, M. Acute toxoplasmosis in squirrel monkeys. Journal of Veterinary Medical Science, v.59, p.593-595, 1997. 